\title{
Sentiment Analysis about Indonesian Lawyers Club Television Program Using K-Nearest Neighbor, Naïve Bayes Classifier, and Decision Tree
}

\author{
Nico Nathanael Wilim ${ }^{1}$, Raymond Sunardi Oetama ${ }^{2}$ \\ ${ }^{1,2}$ Information Systems, Universitas Multimedia Nusantara, South Tangerang, Indonesia \\ 1nico.wilim@student.umn.ac.id, ${ }^{2}$ raymond@umn.ac.id
}

Accepted on March 16, 2021

Approved on May 17, 2021

\begin{abstract}
Indonesia Lawyers Club (ILC) is a talk show on TVOne that discusses topics around public phenomena, legal issues, crime, and other similar topics. In 2018, ILC won the Panasonic Gobel Awards as the best news talk show program. But in 2019, ILC failed to win the award which was won by Mata Najwa which featured a talk show event that appeared on Trans7. As one of the television shows that has won awards, ILC has pros and cons for its shows from the public. This study applies a sentiment analysis approach to examine public opinion on Twitter about Mata Najwa and ILC in 2018 and 2019. This study applies K-Nearest Neighbor, Naïve Bayes Classifier, and Decision Tree classification algorithm to validate the result. The contribution of this study is to show that public opinion on Twitter can be examined to figure out community sentiment on a tv talk show as well as to confirm the Award winner of TV Talkshow.
\end{abstract}

Index Terms-datamining; decision tree; K-NN; Naïve Bayes classifier; sentiment analysis

\section{INTRODUCTION}

Sentiment analysis is a process for determining an opinion or response regarding a particular product or topic. Sentiment analysis can be useful for overcoming several problems, one of which is determining how people respond to a television broadcast [1].

One most popular TV talk shows in Indonesia is Indonesia Lawyers Club (ILC). ILC is a talk show on TVOne that features dialogues that discuss topics around public phenomena and legal or criminal issues [2]. According to Liputan6.com, ILC has been nominated several times to win an award from the Panasonic Gobel Awards. The last award that was won in 2018 was the 2018 Panasonic Gobel Awards in the News Talkshow Program category. However, in 2019, ILC only received a nomination at the Panasonic Gobel Awards because it lost to Mata Najwa, which featured Talkshow like ILC.
The Award winner is calculated from the rating. The value of the rating is especially important for the survival of a television show, but it does not show that the quality level of the shows. Viewers often provide their opinions on television shows through social media, one of which is Twitter [2]. The opinion is an expression of the belief that holds together among members of a group or public, about a controversial issue that concerns the public interest. Opinions are not always logical, formless, always ambivalent, contradictory, and easy to change [3]. Public opinion on ILC can be made from tweets taken from Twitter, this is because quite a lot of Twitter users also watch ILC.

This study applies a sentiment analysis approach to calculate public opinion on Twitter about ILC and Mata Najwa in 2018 and 2019. This study will compare the results of public opinions on ILC and Mata Najwa and will be validated by using three different algorithmic methods for classification, namely K-Nearest Neighbor, Naïve Bayes Classifier, and Decision Tree.

\section{METHODOLOGY}

\section{A. Sentiment Analysis}

Data Mining is an analysis of the process of seeking knowledge in a database. This knowledge can be interpreted as data patterns or relationships between valid data that have not been known before [4]. Sentiment analysis is usually done to seek public or customer opinion on a product or service that is owned by a company, organization, or entity [5]. Sentiment analysis can also be interpreted as learning an opinion, problem, feeling, or emotion from someone or the public in responding to something in the form of text or writing. In determining a sentiment, it is done by calculating some of the words contained in sentences, documents, or text [6]. Rapidminer is software that can be used to process data mining. The process that can 
be carried out by RapidMiner in text mining is about text analysis, finding patterns from large datasets, and mixing them with various statistical methods, artificial intelligence, and databases.

In analyzing sentiments, several steps need to be taken to get the best results. The steps consist of data collection, data pre-processing, and sentiment classification. Fig. 1 shows the steps used in the analysis of sentiment analysis in this study.

\section{B. Data Collecting}

Data collection uses Python to retrieve data on Twitter from 2018 and 2019. Data collection for ILC uses the keywords "IndonesiaLawyersClub", "ILC", and "ILCtvone" while Mata Najwa uses the keywords "Mata Najwa". After getting the data, the next data is selected which is an opinion, and labeled manually by three volunteers as many as 30 tweets per month in 2018 and 2019, respectively. Rather than applying the single peer reviewer method, the benefit of applying the three peer-reviewing methods is to increase the accuracy of the manual review process [7]. An example of the labeling process result can be seen in Fig. 2.

\begin{tabular}{|c|c|c|}
\hline timestamp & text & sentimen \\
\hline $02 / 01 / 2018$ & $\begin{array}{l}\text { Saya senyum sambil geleng2 Den, semoga di } \\
\text { undang @ILCtvone kembali. } \\
\text { https://twitter.com/dennysiregar7/status/948 } \\
\text { 194058484072448Â â€| }\end{array}$ & positif \\
\hline $02 / 01 / 2018$ & Jangan ah mas.. Kasian di ILC cuma jadi badut. & negatif \\
\hline $04 / 01 / 2018$ & Pribumi anti fpi...... Allahuakbar & negatif \\
\hline $04 / 01 / 2018$ & Drama Sandal Jepit dan Kaos Oblong.... & negatif \\
\hline $04 / 01 / 2018$ & Hoax membangun..... & negatif \\
\hline $04 / 01 / 2018$ & $\begin{array}{l}\text { Bagusnya.... Keterlibatan Anggota TNI aktif } \\
\text { maupun baru mengundurkan diri untk menjadi } \\
\text { kepala daerah }\end{array}$ & positif \\
\hline
\end{tabular}

Fig. 2. Labeling

\section{Preprocessing}

After collecting and labeling the data, the next step is to pre-process the data. As can be seen in Figure 3, the preprocessing consists of several processes from Cleansing to Weighting word. The sub Operators of the Document Process Operator can be seen in Fig. 4.

- Cleansing is the step to remove duplicate data, URLs and symbols, numbers, and punctuation that are not needed from text such as exclamation marks, question marks, quotation marks, and so forth. For example: "Sebuah Program televisi 'Kriminal',tidak dicocokan untuk anak! www.kriminalberita.com" becomes "Sebuah Program televisi Kriminal tidak dicocokan untuk anak".

- Case folding is a step to make a sentence into uppercase or lowercase letters. In this study, all letters are changed to be small to facilitate the next process". For example: "Sebuah Program televisi Kriminal tidak dicocokan untuk anak" becomes "sebuah program televisi kriminal tidak dicocokan untuk anak".

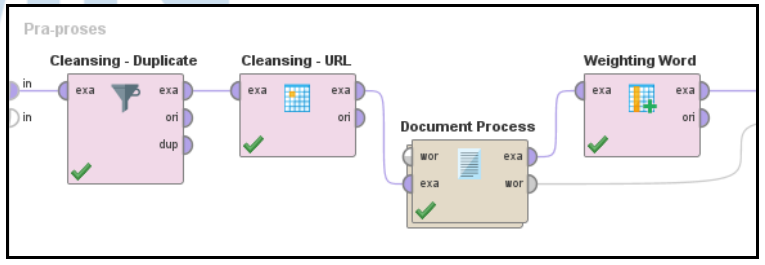

Fig. 3. Data preprocessing operators

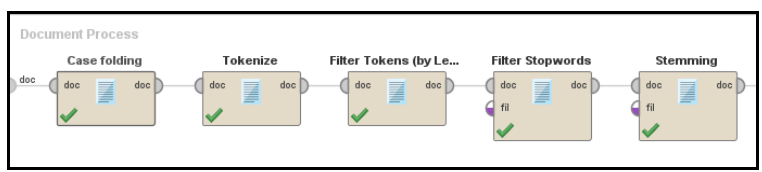

Fig. 4. Sub operators of the document process operator

- Tokenization is a step to break or cut a sentence or document into several parts or words called tokens. There are three types of tokens, namely unigram, bigram, and trigram [8]. In this research, the type of token used is 
unigram, which is the breakdown of documents into one word. For example: "sebuah program televisi kriminal tidak dicocokan untuk anak" becomes "sebuah, program, televisi, kriminal, tidak, dicocokan, untuk, anak".

- Filtering is a step to eliminate words that often appear, but are not needed or do not have meaning. Words that appear in large numbers and are considered to have no meaning are called stopwords. For example: "sebuah, program, televisi, kriminal, tidak, dicocokan, untuk, anak" becomes "program, televisi, kriminal, tidak, dicocokan, anak".

- Stemming is a step to make all words that have an affix or suffix into basic words by the correct Indonesian rules. Stemming is done by removing each prefix and suffix in the word prefix or suffix. For example: "program, televisi, kriminal, tidak, dicocokan, anak" becomes "program, televisi, kriminal, tidak, cocok, anak".

- Weighting word is the final step from data preprocessing to calculate a score or a value on the frequency of the occurrence of words in a document or text. One method for weighting words is term frequency-inverse document frequency (TF-IDF). TF-IDF refers to a weighting method that unites two concepts, namely Term Frequency, and Document Frequency. The term frequency is a concept in which weighting is applied by finding the frequency or frequency of a term occurring in a document or text. Each document or text usually has a different length, so a word may appear more in a long document or text compared to a short document or text. So term frequency is usually divided by the length of the document or the number of words in the document. Document frequency is the number of documents or text in which a word appears. The lower the frequency of occurrence, the lower the value. In calculating the Frequency of the term, all words in it are usually considered important or significant. Therefore, it is very necessary to calculate TF-IDF, where scores can be obtained using an equation [9].

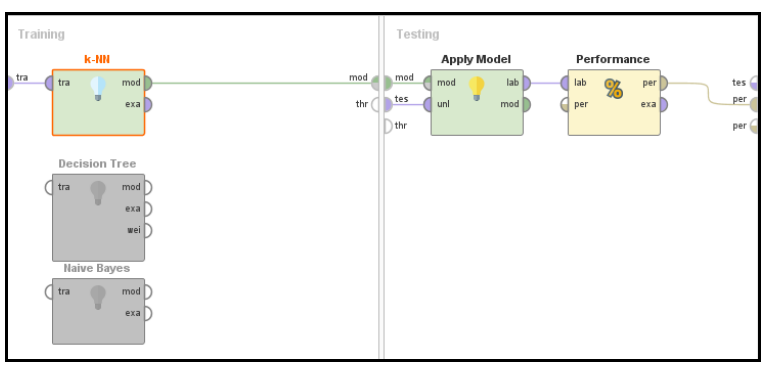

\section{Classification}

Sentiment classification is the step in which all pre-processed data will be further processed with a classification algorithm. This study using three classification algorithms, namely Decision Tree, K-Nearest Neighbor, and Naïve Bayes Classifier.

Fig. 5 shows a sentiment classification operator. In this sentiment classification operator, there are several sub-operators and sub-sub-operators. The sub operator there are 2 namely Cross-Validation and Apply Model (2). In Cross-Validation, there are 5 sub-sub-operators which are divided into 2 parts, training and testing. The part that includes training is the method or algorithm, namely K-NN, Decision Tree, and Naïve Bayes. The parts that include testing are Apply Model and Performance.

The use of K-NN in the illustration Fig. 6 where there are two classes, namely circles and triangles. But there is new data that is not yet known which class is marked with a red square shape. To find out the class of a square, we need the rule to determine the class [4]. In this example, $K=3$. The value of $K=3$ means that the class is classified according to the 3 closest members of its neighbor. Based on the value of $\mathrm{K}=3$, there are 2 classes of circles and 1 class of triangles. So the circle value is greater than the triangle and square data can be classified into circle classes.

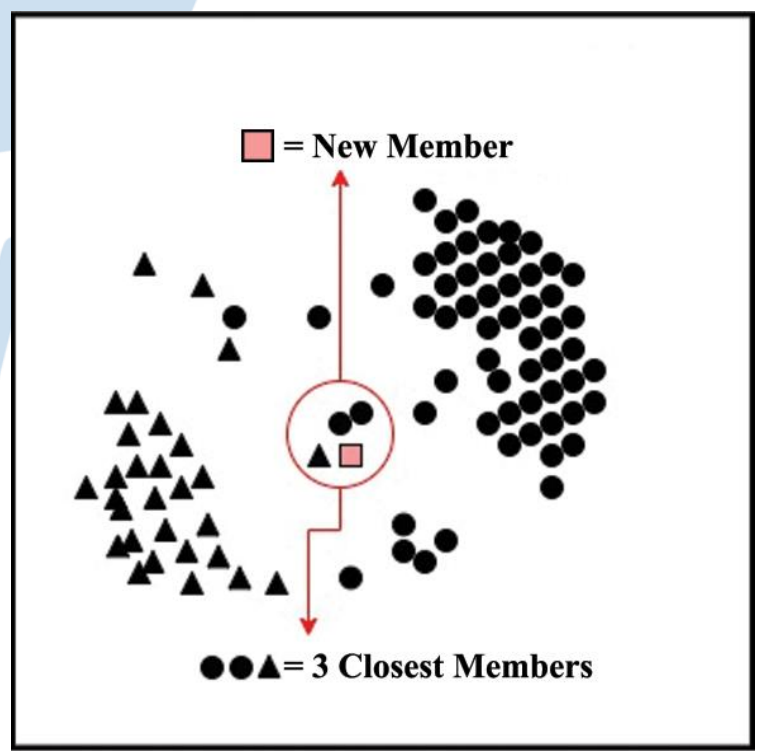

Fig. 6. K-Nearest Neighbor method [4]

As a method known for using conditional probabilities or opportunities, the Naïve Bayes Classifier is formulated as follows [4].

$$
P(H \mid X)=\frac{P(X \mid H) P(H)}{P(X)}
$$

Fig. 5. Cross-validation operator 
Equation 1 is where $\mathrm{X}$ is the proof or data while $\mathrm{H}$ is the hypothesis. $\mathrm{P}(\mathrm{H} \mid \mathrm{X})$ is the probability that the hypothesis $\mathrm{H}$ is true for proof $\mathrm{X}$. $\mathrm{P}(\mathrm{X} \mid \mathrm{H})$ is the probability for proof $\mathrm{X}$ is true for hypothesis $\mathrm{H}$. $\mathrm{P}(\mathrm{H})$ is the probability that the hypothesis $\mathrm{H}$ was true for each object the data does not care about the values of its attributes, while $\mathrm{P}(\mathrm{X})$ is the previous probability for the data object $\mathrm{X}$.

Decision Tree is a hierarchical model in which local areas are identified as a series of recursive separations by decision nodes in the test function. Decisions in the decision tree are most used by logical methods. In Fig. 7, the Decision Tree is a tree-shaped flowchart structure, in which each internal node (not a leaf node) tests an attribute, each branch represents the test result, and each leaf node (or terminal node) indicates the class label. While the node at the top of the decision tree is the root node.

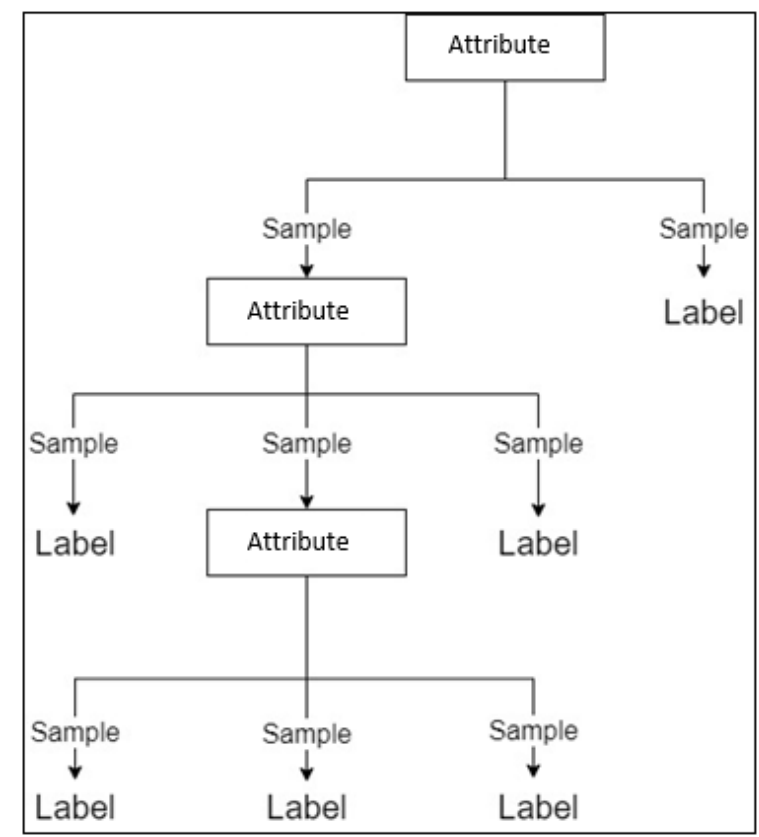

Fig. 7. Decision tree [4]

\section{RESULTS}

This section is an explanation of the results of the analysis process that has been done.

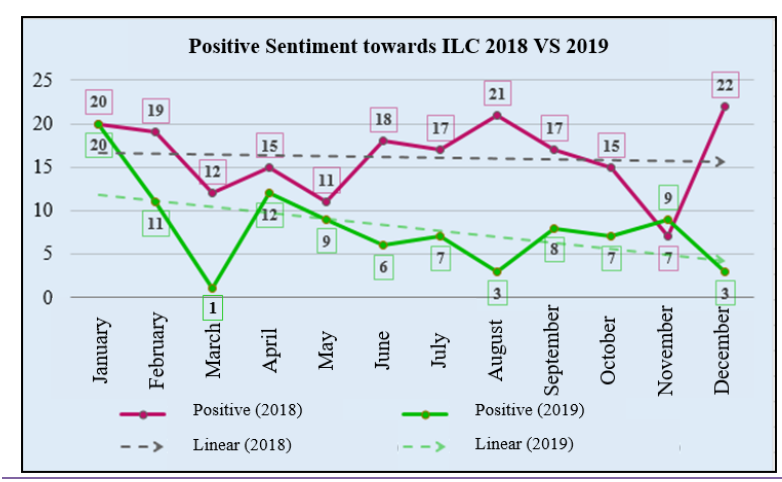

IJNMT (International Journal of New Media Technology), Vol. 8, No. 1 | June 2021
Fig. 8. Comparison of sentiments towards ILC in 2018 and 2019

\section{A. Manual Analysis}

A comparison of positive sentiment in ILC in 2018 and 2019 can be seen in Fig. 8. The trend shows a quite large difference between the number of positive sentiments in 2018 and 2019. It also shows that there was a decline in 2018, however, in 2019 there was even more decline, especially in March 2019 where the positive sentiment results fell to 1 in 30 tweets. As shown in Table I, the total positive sentiment of the ILC in 2018 was 194, while in 2019 it was 96. The total negative sentiment of ILC in 2018 was 166 while in 2019 it was 264. A decrease in the number of positive sentiments with a difference of 98 sentiments followed by an increase in negative sentiment with the same difference.

TABLE I. SENTIMENT TOWARDS ILC

\begin{tabular}{|l|c|c|c|c|}
\hline & \multicolumn{2}{|c|}{ Positive } & \multicolumn{2}{c|}{ Negative } \\
\hline Month & $\mathbf{2 0 1 8}$ & $\mathbf{2 0 1 9}$ & $\mathbf{2 0 1 8}$ & $\mathbf{2 0 1 9}$ \\
\hline January & 20 & 20 & 10 & 10 \\
\hline February & 19 & 11 & 11 & 19 \\
\hline March & 12 & 1 & 18 & 29 \\
\hline April & 15 & 12 & 15 & 18 \\
\hline May & 11 & 9 & 19 & 21 \\
\hline June & 18 & 6 & 12 & 24 \\
\hline July & 17 & 7 & 13 & 23 \\
\hline August & 21 & 3 & 9 & 27 \\
\hline September & 17 & 8 & 13 & 22 \\
\hline October & 15 & 7 & 15 & 23 \\
\hline November & 7 & 9 & 23 & 21 \\
\hline December & 22 & 3 & 8 & 27 \\
\hline Total & $\mathbf{1 9 4}$ & $\mathbf{9 6}$ & $\mathbf{1 6 6}$ & $\mathbf{2 6 4}$ \\
\hline
\end{tabular}

A comparison of Mata Najwa's positive sentiment in 2018 and 2019 can be seen in Figure 9. The trend line shows a slight difference between the number of positive sentiments in 2018 and 2019. It also shows a slight increase in 2018, but it happened a decline although not very significant in 2019. As shown in Table II, the total positive sentiment of Mata Najwa in 2018 was 215 while in 2019 it was 227. The total negative sentiment of Mata Najwa in 2018 was 155 while in 2019 it was 133. An increase in the number of sentiments positive with a difference of 12 sentiments followed by a decrease in negative sentiment by the same difference. 


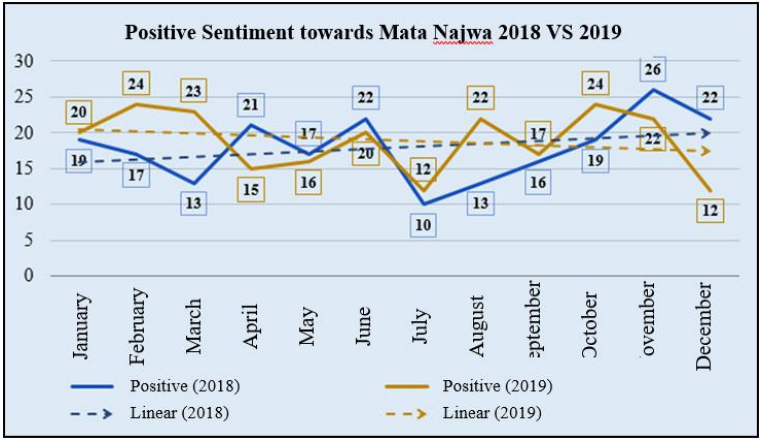

Fig. 9. Comparison of sentiments towards Mata Najwa in 2018 and 2019

TABLE II. SENTIMENTS TOWARDS MATA NAJWA

\begin{tabular}{|l|c|c|c|c|}
\hline & \multicolumn{2}{|c|}{ Positive } & \multicolumn{2}{c|}{ Negative } \\
\hline Month & $\mathbf{2 0 1 8}$ & $\mathbf{2 0 1 9}$ & $\mathbf{2 0 1 8}$ & $\mathbf{2 0 1 9}$ \\
\hline January & 19 & 20 & 11 & 10 \\
\hline February & 17 & 24 & 13 & 6 \\
\hline March & 13 & 23 & 17 & 7 \\
\hline April & 21 & 15 & 9 & 15 \\
\hline May & 17 & 16 & 13 & 14 \\
\hline June & 22 & 20 & 18 & 10 \\
\hline July & 10 & 12 & 20 & 18 \\
\hline August & 13 & 22 & 17 & 8 \\
\hline September & 16 & 17 & 14 & 13 \\
\hline October & 19 & 24 & 11 & 6 \\
\hline November & 26 & 22 & 4 & 8 \\
\hline December & 22 & 12 & 8 & 18 \\
\hline Total & $\mathbf{2 1 5}$ & $\mathbf{2 2 7}$ & $\mathbf{1 5 5}$ & $\mathbf{1 3 3}$ \\
\hline
\end{tabular}

Comparison between ILC and Mata Najwa in each year can be seen in Fig. 10 and Fig. 11. In 2018, the ILC trend line tends to decrease while Mata Najwa tends to go up. However, the difference is still not that big compared to 2019, where the trend line on the ILC is far below Mata Najwa and also tends to fall, while Mata Najwa is far above and tends to go up. In 2019, ILC suffered defeat and was defeated by Mata Najwa.

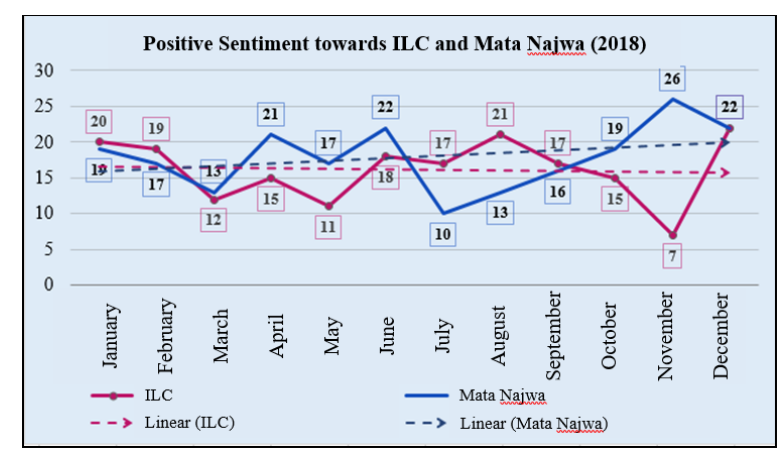

Fig. 10. Comparison of positive sentiments towards ILC and Mata Najwa in 2018

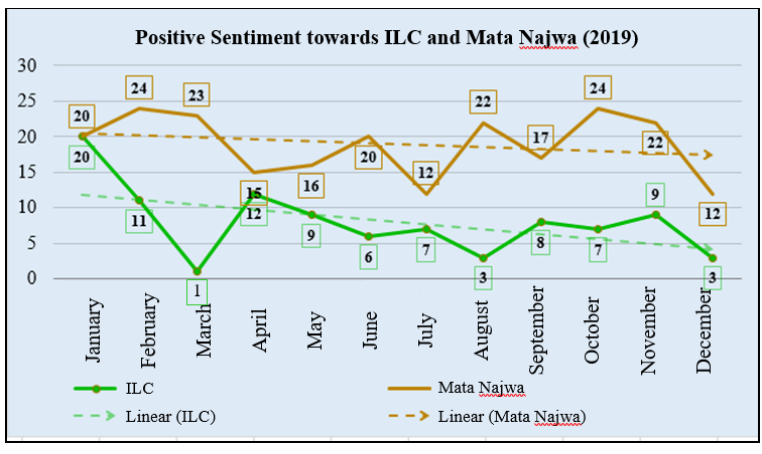

Fig. 11. Comparison of positive sentiments towards ILC and Mata Najwa in 2019

\begin{tabular}{|c|c|}
\hline \multirow{2}{*}{\multicolumn{2}{|c|}{$2 / 03 / 2019$ wah tv one udah keliatan jd pengecut ini gegara sering disebut tv Pendukung no u negatif }} \\
\hline & \\
\hline teruskan gayamu 2 minggu terakir,maka & \\
\hline i sejarah utk $n$ & anegatif \\
\hline /03/2019 tanda2 @ILCtv1 akan ditinggalkan penggemarnya... & negatif \\
\hline 03/2019 sudahhh gak menarik lagii .. & negatif \\
\hline 12/03/2019 ILC akhir akhir ini kurang greget. Why? & negatif \\
\hline juga muak ma ILC & negatif \\
\hline /03/2019 Karni dah ga netral lagi, kalo saya sih sdh malas nonton. & negatif \\
\hline si olh para laywer hand & \\
\hline 20/03/2019 Betul...@lLCtv1 hanya dijadikan tempat utk menghina dan n & snegatif \\
\hline 20/03/2019 Setuju .jgn nonton tv one & negatif \\
\hline 21/03/2019 Setuju banget! Sudah gak ada nilai lawyer nya sama sekali! & negatif \\
\hline /03/2019 Saat ini ILC lebih cocok jadi IPC (indonesian politician club). & Ea \\
\hline 21/03/2019 Paling ogah nonton ILC sekarang. & negatif \\
\hline 103/2019 Dengerin bang karni ngos ngosan a & negatif \\
\hline 21/03/2019 menurut saya mungki & negatif \\
\hline 24/03/2019 ILC tanpa Rocky Gerung seperti sayur tanpa garam & negatif \\
\hline
\end{tabular}

Fig. 12. Data set on March 2019

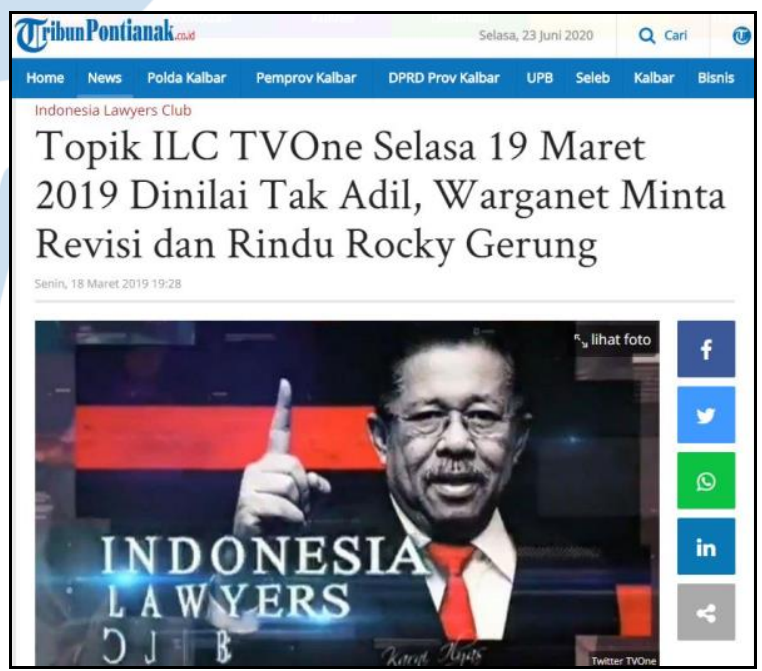

Fig. 13. News about citizens asking for revisions to the topic of ILC and the presence of Rocky Gerung [10] 


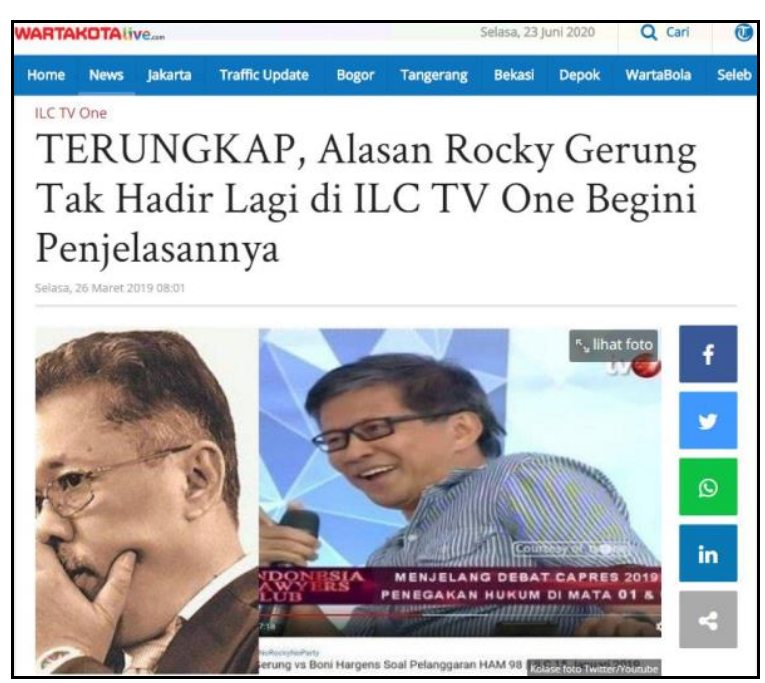

Fig. 14. News about the reason Rocky Gerung is no longer present at ILC [11]

In March 2019, the positive sentiment towards ILC decreased to one sentiment. After further analysis, it turns out that in the March 2019 crawl text, there is a reason why sentiment has declined dramatically which can be seen in Fig. 12. It occurs since the disappointment with ILC because one of its sources, Rocky Gerung was not presented which is highlighted in yellow. Fig. 13 contains contra the community against the topic of the ILC discussion and asked to be revised, and also their longing for Rocky Gerung, while Fig. 14 contains the reason Rocky Gerung is no longer present in the ILC.

As a result of this manual analysis, public opinion on Twitter can be applied to explain the Panasonic Gobel Award Winner between ILC and Mata Najwa. In 2018. ILC outperforms Mata Najwa. This is matched with the public opinion result. ILC is above Mata Najwa before October 2018. Afterward, more positive opinions for Mata Najwa in 2019, and Mata Najwa comes as the winner this year.

\section{B. Analysis Using Rapidminer}

The analysis using RapidMiner is applied to validate the manual labeling results by predicting them using several algorithms. This analysis is performed by using algorithms and operators in Rapidminer. The main operators can be seen in Fig. 15. The analysis process is done by retrieving data from Twitter and then processed using a series of operators created in the RapidMiner application. The series starts from the Read Dataset Training which continues to the Preprocessing until Sentiment Classification.

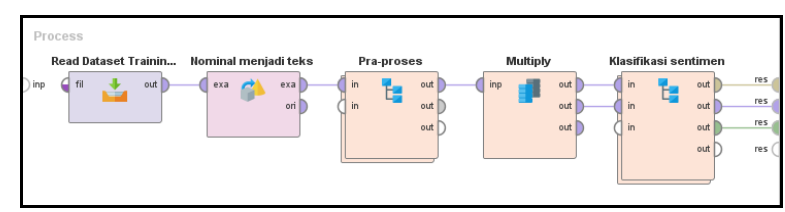

Fig. 15. Main operators

\begin{tabular}{|l|l|l|l|l|l|}
\hline sentimen & prediction... & text & timestamp & adem & adil \\
\hline positif & negatif & senyum geleng den semoga undang ilctvone & Jan 2, 2018 & 0 & 0 \\
negatif & negatif & mas kasian ilc badut & Jan 2, 2018 & 0 & 0 \\
\hline negatif & negatif & pribumi anti fpi allahuakbar & Jan 4, 2018 & 0 & 0 \\
\hline
\end{tabular}

Fig. 16. Prediction results

Fig. 16 shows the results of the RapidMiner process in which the classification carried out using the algorithm method produces predictions which if positive sentiment and positive prediction will become True Positive and vice versa for negative sentiment.

TABLE III. CONFUSION MATRIX ILC 2018

\begin{tabular}{|l|c|c|c|c|}
\hline \multicolumn{1}{|c|}{ Methods } & True Positive & False Positive & True Negative & False Negative \\
\hline Decision Tree & 186 & 8 & 22 & 144 \\
\hline Naïve Bayes & 118 & 76 & 123 & 43 \\
\hline k-NN $(k=7)$ & 149 & 45 & 82 & 84 \\
\hline
\end{tabular}

TABLE IV. CONFUSION MATRIX ILC 2019

\begin{tabular}{|l|c|c|c|c|}
\hline \multicolumn{1}{|c|}{ Methods } & True Positive & False Positive & True Negative & False Negative \\
\hline Decision Tree & 20 & 76 & 255 & 9 \\
\hline Naive Bayes & 58 & 38 & 195 & 69 \\
\hline k-NN (k=9) & 25 & 71 & 252 & 12 \\
\hline
\end{tabular}

Tables III and IV contain data in the form of the number of positive and negative sentiments of ILC in 2018 and 2019 using the three algorithms. Positive sentiments consist of true positives and false positives, while negative sentiments consist of true negatives and false negatives. The number of true positives in 2018 is more than in 2019.

Whilst, the comparison of Mata Najwa's positive sentiment in 2018 and 2019 can be seen in Table V and VI. By using the three algorithms, it can be stated that the number of True Positive in 2019 is more than in 2019.

TABLE V. CONFusion Matrix Mata Najwa 2018

\begin{tabular}{|l|c|c|c|c|}
\hline \multicolumn{1}{|c|}{ Methods } & True Positive & False Positive & True Negative & False Negative \\
\hline Decision Tree & 196 & 5 & 27 & 132 \\
\hline Naïve Bayes & 157 & 44 & 95 & 64 \\
\hline k-NN (k=13) & 159 & 42 & 80 & 79 \\
\hline
\end{tabular}

TABLE VI. CONFUSION MATRIX MATA NAJWA 2019

\begin{tabular}{|l|c|c|c|c|}
\hline \multicolumn{1}{|c|}{ Methods } & True Positive & False Positive & True Negative & False Negative \\
\hline Decision Tree & 222 & 5 & 12 & 121 \\
\hline Naïve Bayes & 151 & 76 & 86 & 47 \\
\hline k-NN $(k=3)$ & 182 & 45 & 77 & 56 \\
\hline
\end{tabular}

TABLE VII. ACCURACY OF ALGORITHMS METHODS

\begin{tabular}{|l|c|c|c|c|}
\hline \multirow{2}{*}{ Methods } & \multicolumn{2}{|c|}{2018} & \multicolumn{2}{c|}{2019} \\
\cline { 2 - 5 } & $I L C$ & Mata Najwa & ILC & Mata Najwa \\
\hline Naïve Bayes & $66.94 \%$ & $70.00 \%$ & $76.39 \%$ & $65.83 \%$ \\
\hline k-NN & $64.17 \%$ & $66.39 \%$ & $76.94 \%$ & $71.94 \%$ \\
\hline Decision Tree & $57.78 \%$ & $61.94 \%$ & $70.28 \%$ & $65.00 \%$ \\
\hline
\end{tabular}


As shown in Table VII, in 2018, Naïve Bayes was the best algorithm, while in 2019 , K-NN was the best algorithm. This means that no algorithm is always at the top. All algorithms are used based on data content and the level of accuracy of certain data is always changing. In 2018, the performance of both Mata Najwa and ILC is fluctuated, as a result, K-NN finds more difficulties to find the nearest neighbor. In such a situation, the conditional probability capability of Naïve Bayes performs better. While in 2019, the public opinion of Mata Najwa is clearly above the ILC. So K-NN can easily separate them into the nearest neighbor. The best accuracy is found on the ILC in 2019 by using K-NN because its public positive opinion in 2018 is above in 2019. So that $\mathrm{K}-\mathrm{NN}$ can separate them easier to the nearest neighbor.

\section{CONCLUSION}

The public opinion on Twitter can be successfully applied to confirm the winner of the Panasonic Gobel Award. As a result of manual analysis, ILC wins in 2018. The number of the positive sentiment of ILC is slightly better than Mata Najwa. But ILC lost in 2019 because its number of positive sentiments is declined whilst Mata Najwa is obviously above ILC. In addition, from 2018 to 2019, the number of positive sentiment for ILC is dramatically decreased, whilst Mata Najwa fluctuated.

Three Algorithms are applied to validate manual labeling results with the highest accuracy is $76.94 \%$ by using K-NN. However, no one algorithm shows the best performance on all data. In 2018, Naïve Bayes was the best algorithm, while in 2019, K-NN was the best algorithm.

\section{ACKNOWLEDGMENT}

This research was carried out by obtaining financial support from Multimedia Nusantara University.

\section{REFERENCES}

[1] Vinodhini, G., and Chandrasekaran, R. "Sentiment Analysis and Opinion Mining: A Survey International Journal of Advanced Research in Sentiment Analysis and Opinion Mining: A Survey". International Journal of Advanced Research in Computer Science and Software Engineering, 2(6), pp.283-292, 2012.

[2] Nurjanah, W. E., Perdana, R. S., and Fauzi, M. A.. "Analisis Sentimen Terhadap Tayangan Televisi Berdasarkan Opini Masyarakat pada Media Sosial Twitter menggunakan Metode K-Nearest Neighbor dan Pembobotan Jumlah Retweet". Jurnal Pengembangan Teknologi Informasi Dan Ilmu Komputer (J-PTIIK) Universitas Brawijaya, 1(12), pp.1750 1757, 2017, https://doi.org/10.1074/jbc.M209498200.

[3] Berliner D, Lambek M, Shweder R, Irvine R, and Piette A. "Anthropology and the study of contradictions". HAU: Journal of Ethnographic Theory, 6(1), pp.1-27, 2016.

[4] Suyanto, S. M. (2017). Data Mining Untuk Klasifikasi Dan Klasterisasi Data. Bandung: Informatika.
[5] Jessica, and Oetama, R. S. (2019). "Sentiment Analysis on Official News Accounts of Twitter Media in Predicting Facebook Stock", 5th International Conference on New Media Studies (CONMEDIA), pp.74-79. http://doi.org/10.1109/conmedia46929.2019.8981836

[6] Calvin, and Setiawan, J. "Using Text Mining to Analyze Mobile Phone Provider Service Quality (Case Study: Social Media Twitter)". International Journal of Machine Learning and Computing, vol. 4, pp. 106-109, 2014. https://doi.org/10.7763/ijmlc.2014.v4.395

[7] Bucur, C. Iulia, T. Kuhn, and D. Ceolin. "Peer reviewing revisited: assessing research with interlinked semantic comments." In Proceedings of the 10th International Conference on Knowledge Capture, pp. 179-187, 2019.

[8] Tiffani I. E.. "Optimization of Naïve Bayes Classifier By Implemented Unigram, Bigram, Trigram for Sentiment Analysis of Hotel Review". Journal of Soft Computing Exploration. Vol. 1, pp. 1-7, 2020.

[9] Bayhaqy, A., Sfenrianto, S., Nainggolan, K., and Kaburuan, E. R. "Sentiment Analysis about E-Commerce from Tweets Using Decision Tree, K-Nearest Neighbor, and Naïve Bayes". International Conference on Orange Technologies, ICOT, pp. 1-6, 2018. http://doi.org/10.1109/ICOT.2018.8705796

[10] R. P. Rizky. Topik ILC TVOne Selasa 19 Maret 2019 Dinilai Tak Adil Warganet Minta Revisi dan Rindu Rocky Gerung, tribunpontianak.co.id, 2019. Retrieved from https://pontianak.tribunnews.com/2019/03/18/topik-ilc-tvoneselasa-18-maret-2019-dinilai-tak-adil-warganet-minta-revisidan-rindu-rocky-gerung.

[11] M. A. Dian, Terungkap Alasan Rocky Gerung Tak Hadir Lagi di ILC TV One Begini Penjelasannya, Wartakota Tribunnews, $2019 . \quad$ Retrieved from https://wartakota.tribunnews.com/2019/03/26/terungkapalasan-rocky-gerung-tak-hadir-lagi-di-ilc-tv-one-beginipenjelasannya. 